\title{
Induction of apoptosis in human hepatocellular carcinoma cells by extracts of Lannea coromandelica (Houtt.) Merr. and Diospyros castanea (Craib) Fletcher
}

\author{
Natthida Weerapreeyakul ${ }^{1}$, Cholpajsorn Junhom², Sahapat Barusrux ${ }^{3^{*}}$ and Thaweesak Thitimetharoch ${ }^{1}$
}

\begin{abstract}
Background: Herbal plants are a preferred source of anticancer agents. This study aims to screen the anticancer activity of a crude extract of twigs of (a) Bombax anceps Pierre var. anceps (BA); (b) Catunaregam tomentosa (Blume ex DC.) Tirveng. (CT); (c) Erythrophleum succirubrum Gagnep. (ES); (d) Lannea coromandelica (Houtt.) Merr. (LC); and (e) leaves and ( $f$ ) twigs of Diospyros castanea (Craib) Fletcher (DC).

Methods: The $50 \%$ ethanol-water extracts were prepared from each plant sample. In vitro anticancer effects of six extracts on the human hepatocellular carcinoma cell line (HepG2) in terms of cytotoxicity were investigated by neutral red assay, apoptosis induction by 4',6-diamidino-2-phenylindole (DAPI) staining, and DNA fragmentation by agarose gel electrophoresis. Normal Vero cells were tested for comparison and to determine cancer selectivity. Gas chromatography-mass spectrometry analysis was performed to identify the compounds in the extracts.

Results: The six crude extracts had different cytotoxicities and were classified into three groups based on their $\mathrm{IC}_{50}$ value and selectivity index (SI). DC (twig) crude extract had both a high cytotoxicity and SI toward HepG2 cells comparable to melphalan $(P=0.023)$. The crude extracts of DC (leaves), LC (twig), and BA (twig) had moderate cytotoxicity and a lower SI. Although all crude plant extracts induced apoptosis in more than $50 \%$ of the DAPI-positive apoptotic HepG2 cells, only DC (twig) and LC (twig) showed laddering in the DNA fragmentation assay. 2-Palmitoylglycerol was the major compound common to both. Pyrogallol and lupeol were the major compounds in DC (twig) crude extract. Hexadecanoic acid and octadecenoic acid were the major compounds in LC (twig) crude extract, which had high toxicity but low selectivity.
\end{abstract}

Conclusion: Ethanolic extracts from DC and LC twigs induced apoptosis in the HepG2 cell line. Pyrogallol and lupeol in DC (twig) might be responsible for the cytotoxicity toward the HepG2 cancer cells.

Keywords: Diospyros castanea, Lannea coromandelica, Hepatocellular carcinoma, HepG2, Cytotoxicity, Apoptosis

\section{Background}

Hepatocellular carcinoma (HCC) in men is the fifth most common malignant tumor in the world and the second most common cause of cancer death [1]. The major risk factors for HCC include infection by hepatitis B and

\footnotetext{
${ }^{*}$ Correspondence: sahapat@kku.ac.th

${ }^{3}$ Faculty of Associate Medical Sciences, Khon Kaen University, Khon Kaen 40002, Thailand

Full list of author information is available at the end of the article
}

hepatitis $\mathrm{C}$ viruses, both of which are endemic in northeastern Thailand [2]. Drug resistance and severe side effects on normal tissues and cells have limited the effectiveness of chemotherapy [3].

Anticancer agents have been found in natural products, such as vincristine and vinblastine from Catharanthus roseus [4], taxol and docetaxel from Taxus brevifolia [5], and camptothecins from Camptotheca acuminata [6-9]. The Plant Genetics Conservation Project (under the patronage of HRH Princess Maha Chakri Sirindhorn)

\section{Biomed Central}

(c) 2016 Weerapreeyakul et al. This article is distributed under the terms of the Creative Commons Attribution 4.0 International License (http://creativecommons.org/licenses/by/4.0/), which permits unrestricted use, distribution, and reproduction in any medium, provided you give appropriate credit to the original author(s) and the source, provide a link to the Creative Commons license, and indicate if changes were made. The Creative Commons Public Domain Dedication waiver (http://creativecommons. org/publicdomain/zero/1.0/) applies to the data made available in this article, unless otherwise stated. 
has reported on the cytotoxic and apoptotic effects of medicinal plants against hepatoma cells [10-13]. Subsequent study was performed on the plants locally found in Thailand which were used in this study including Lannea coromandelica (Houtt.) Merr. (LC); Catunaregam tomentosa (Blume ex DC.) Tirveng. (CT); Erythrophleum succirubrum Gagnep (ES); Diospyros castanea (Craib) Fletcher (DC); and Bombax anceps Pierre var. anceps (BA).

DC belongs to the family Ebenaceae, which is widespread in the tropics and subtropics [14]. Many Diospyros species have medicinal uses in Chinese, Ayurvedic, and African traditional medicine. Almost all the major parts of these plants have been used as medicines and reported to have biological and pharmacological activities [14]. LC belongs to the family Anacardiaceae. It is a deciduous tropical tree widely distributed in Bangladesh, India, and some other tropical countries [15-18]. CT belongs to the family Rubiaceae and has been used to treat diabetes mellitus, cancer, and tuberculosis. It possesses antimicrobial, antifungal, hypotensive, analgesic, antimalaria, antioxidant, and antileukemia pharmacological properties [19]. ES belongs to the family Leguminosae (subfamily Caesalpinioideae) and is used in Thai traditional medicines for fever and skin disease. Some isolated compounds (cassaine diterpenoid dimers) from this family contribute to anticancer activity by decreasing apoptosis inhibitors or increasing apoptosis inducers; this leads to tumor necrosis factor (TNF)-related apoptosisinducing ligand resistance in human gastric adenocarcinoma cells [20]. BA belongs to the family Bombacaceae. Plants in this family are active against many different diseases [21-24] (Table 1); however, the dichloromethane extract from the root of $B$. malabaricum is inactive in the human epidermoid carcinoma (KB) and human cervical carcinoma (HeLa) cell lines [25].

To our knowledge, the mechanism of anticancer effect of these five plants on HCC is still unknown. This study aims to screen the anticancer activity of a crude $50 \%$ ethanol-water extract of twigs of (a) BA; (b) CT; (c) ES; (d) $\mathrm{LC}$; and (e) leaves and (f) twigs of DC. The cytotoxic and apoptotic actions of the extracts were investigated with a human HCC cell line (HepG2) and compared with their effects on normal Vero cells. One advantage of using the normal Vero cell line is that Vero cell line multiplies indefinitely while primary liver cells have a limited lifetime and die after a given number of generations. Consequently, the Vero cell line is easy to handle and represents an unlimited self-replicating source with a relatively high degree of homogeneity. We then analyzed major compounds common to the different effective extracts using gas chromatography-mass spectrometry (GC-MS).

Table 1 Ethnopharmacology, pharmacological activities, and taxonomic classification of plants

\begin{tabular}{|c|c|c|}
\hline Scientific name (voucher specimen no.) $)^{a}$ & Part of plant & Traditional uses/pharmacological activity \\
\hline \multirow{4}{*}{$\begin{array}{l}\text { Diospyros castanea (Craib) Fletcher. } \\
\text { (TT-OC-SK-1030) } \\
\text { Family: Ebenaceae }\end{array}$} & Leaf & $\begin{array}{l}\text { Diospyros: lumbago, astringent, febrifuge, anti cancer activ- } \\
\text { ity, anti HIV activity, anti-inflammatory activity [14] }\end{array}$ \\
\hline & Fruit & Diospyros: carminative, astringent, cure biliousness [14] \\
\hline & Seed & Diospyros: sedative [14] \\
\hline & Bark & Diospyros: bitter, astringent and febrifuge [14] \\
\hline \multirow{3}{*}{$\begin{array}{l}\text { Lannea coromandelica (Houtt.) Merr. } \\
\text { (TT-OC-SK-993) } \\
\text { Family: Anacardiaceae }\end{array}$} & Stem bark & $\begin{array}{l}\text { LC: elephantiasis, impotence, ulcers, halitosis, heart disease, } \\
\text { dysentery, gout rheumatism [15] }\end{array}$ \\
\hline & Bark (ethanol, acetone) & $\begin{array}{l}\text { LC: wound healing, antimicrobial activity in the form of } \\
\text { simple ointments [16] }\end{array}$ \\
\hline & Root bark, stem bark (crude methanol) & $\begin{array}{l}\text { LC: hypotensive activity [17], L. velutina: antioxidation activity } \\
\text { [18] }\end{array}$ \\
\hline $\begin{array}{l}\text { Catunaregam tomentosa (Blume ex DC.) Tirveng. } \\
\text { (TT-OC-SK-1015) } \\
\text { Family: Rubiaceae }\end{array}$ & Crude (ethanol) & $\begin{array}{l}\text { R. cordifolia: diabetes mellitus, cancer, TB, antimicrobial, anti- } \\
\text { fungal, hypotension analgesic, anti-malarial, antioxidant, } \\
\text { anti-leukemic, mutagenic functions [19] }\end{array}$ \\
\hline $\begin{array}{l}\text { Erythrophleum succirubrum Gagnep. } \\
\text { (TT-OC-SK-1082) } \\
\text { Family: Leguminosae-Caesalpinioideae }\end{array}$ & Bark (methanol) & ES: anticancer activity [20] \\
\hline \multirow{4}{*}{$\begin{array}{l}\text { Bombax anceps Pierre var. anceps } \\
\text { (TT-OC-SK-1074) } \\
\text { Family: Bombacaceae }\end{array}$} & Crude (methanol) & B. ceiba: antioxidant activity [21] \\
\hline & Root $\left(\mathrm{H}_{2} \mathrm{O} /\right.$ acetone $)$ & $\begin{array}{l}\text { B. malabaricum: demulcent, diuretic, restorative, aphrodisiac, } \\
\text { emetic properties, astringent, antifungal activity, cytotox- } \\
\text { icity, anti-HIV activity [22] }\end{array}$ \\
\hline & Stem bark & B. ceiba: anticancer activity and anti-inflammation [23] \\
\hline & Stem bark (methanol) & B. ceiba: antiangiogenic activity [24] \\
\hline
\end{tabular}

a TT-OC-SK Thaweesak Thitimetharoch, Orasa Chaichumporn, and Sureerat Kaewsaart 


\section{Methods}

\section{Chemicals and reagents}

Dulbecco's modified Eagle's medium (DMEM), fetal bovine serum, penicillin, and streptomycin were purchased from GIBCO $^{\mathrm{TM}}$ (Invitrogen, Grand Island, New York, USA). Acetonitrile (HPLC grade; Fisher Scientific, Leicestershire, UK), orthophosphoric acid (analytical grade; $\mathrm{BHD}$, Merseyside, UK), and ultrapure water from a Milli-Q system (Millipore, Billerica, Massachusetts, USA) were used for the mobile phase preparation. Dimethylsulfoxide (DMSO), ethidium bromide, the fluorescence dye 4',6-diamidino-2-phenylindole (DAPI), sodium bicarbonate $\left(\mathrm{NaHCO}_{3}\right)$, neutral red, and a standard anticancer drug (melphalan) were purchased from Sigma-Aldrich (Darmstadt, Germany). A FlexiGene DNA kit was purchased from Qiagen (Hilden, Germany), agarose (molecular grade) was purchased from Bio-Rad (Hercules, California, USA), and a DNA ladder with stain was purchased from SibEnzyme (Novosibirsk, Russia). Isopropyl alcohol (biotechnology grade) was purchased from BioBasic Inc. (Amherst, New York, USA) and $100 \mathrm{bp}+1.5 \mathrm{~Kb}$ DNA ladder with stain was purchased from SibEnzyme (Novosibirsk, Russia). All other reagents used in this study were purchased from Sigma Chemicals Co. (St. Louis, Missouri, USA). An Annexin V-FITC Apoptosis Detection Kit was purchased from Bender MedSystems GmbH (Vienna, Austria).

\section{Preparation of plant extracts}

Leaves and twigs of LC, CT, ES, BA, and DC were collected in Khon Kaen Province, Thailand. They were authenticated using taxonomic methods by Assistant Professor Thaweesak Thitimetharoch., Faculty of Pharmaceutical Sciences, Khon Kaen University. The descriptions of plant species were determined using the Flora of Thailand and the Thai Forest Bulletin [26-30]. The specimen vouchers were deposited at the medicinal herbarium of the Faculty of Pharmaceutical Sciences, Khon Kaen University, Khon Kaen province, Thailand. All plants were extracted and prepared using the following method. The crude $50 \%$ ethanol-water extract was obtained as previously described [12]. Briefly, dried plants were cut and macerated with $50 \%$ ethanol and water in a ratio of $1 \mathrm{~g}$ dried plant to $6 \mathrm{ml}$ of extract solvent. This mixture was left for 7 days with occasional shaking. The solvent was filtered with Whatman filter paper No. 1, distilled in vacuo with a rotary evaporator below $40{ }^{\circ} \mathrm{C}$, and freezedried to obtain the crude extracts. The percentage yields of the extracts and the plant parts from which they were obtained are shown in Table 2. Stock solution of each extract was freshly prepared in DMSO to make $100 \mathrm{mg} /$ $\mathrm{mL}$ stock solution and further diluted with culture media to create a working solution. In all experiments, the concentrations of extracts (working solution) ranged from 10 to $500 \mu \mathrm{g} / \mathrm{mL}$ and the final concentration of DMSO was $<1 \%$ to retain the percentage cytotoxicity of DMSO at $<10 \%$.

\section{Cell culture}

The HepG2 cells (human HCC cell line) and Vero cells (normal kidney epithelial cells) were grown in DMEM supplemented with $10 \%$ fetal bovine serum, $100 \mathrm{U} / \mathrm{mL}$ penicillin, and $100 \mu \mathrm{g} / \mathrm{mL}$ streptomycin. The cell lines were cultured in an incubator (Procell; Jencons-PLS, USA) at $37{ }^{\circ} \mathrm{C}$ in a humidified atmosphere containing $5 \%$ carbon dioxide $\left(\mathrm{CO}_{2}\right)$.

\section{Cytotoxicity assay}

Cell viability was measured using a neutral red (NR) assay. Cells were seeded at a density of $3 \times 10^{5}$ cells per well in 96-well plates (Costar 3599; Corning Inc., USA) in the medium, and incubated for $24 \mathrm{~h}$. The stock solutions of plant extracts in DMSO were diluted with DMEM to the desired concentrations $(10-500 \mu \mathrm{g} / \mathrm{mL})$.

Table 2 Cytotoxicity of plant extracts in HepG2 and vero cells (mean \pm SD) $(n=5)$

\begin{tabular}{|c|c|c|c|c|c|}
\hline \multirow[t]{2}{*}{ Plant } & \multirow[t]{2}{*}{ Part used } & \multirow[t]{2}{*}{$\%$ yield } & \multicolumn{2}{|c|}{$I C_{50} \pm S D(\mu \mathrm{g} / \mathrm{mL})$} & \multirow[t]{2}{*}{ SI } \\
\hline & & & HepG2 & Vero & \\
\hline L. coromandelica (LC) & Twig & 6.01 & $307.12 \pm 15.97^{a}$ & $489.37 \pm 37.43$ & $1.6^{\mathrm{a}}$ \\
\hline C. tomentosa (CT) & Twig & 6.88 & $316.70 \pm 34.82$ & $294.59 \pm 76.25$ & 0.9 \\
\hline E. succirubrum (ES) & Twig & 8.94 & $207.89 \pm 40.89$ & $94.18 \pm 29.10$ & 0.4 \\
\hline D. castanea (DC) & Leaves & 7.23 & $147.12 \pm 10.34^{a}$ & $237.11 \pm 43.03$ & $1.6^{\mathrm{a}}$ \\
\hline D. castanea (DC) & Twig & 8.74 & $112.35 \pm 18.26^{b}$ & $>500$ & $>4.5^{b, c}$ \\
\hline B. anceps (BA) & Twig & 5.96 & $212.74 \pm 27.01^{a}$ & $>500$ & $2.3^{\mathrm{a}}$ \\
\hline Melphalan & & & $39.79 \pm 7.62$ & $178.98 \pm 15.25$ & 4.5 \\
\hline
\end{tabular}

\footnotetext{
a Moderate cytotoxicity with lower selectivity index $(\mathrm{SI}<3.0)$

b High cytotoxicity with higher selectivity index ( $\mathrm{SI}>3.0$ ) to HepG2 cell lines

c Non-significant difference vs. melphalan $(P>0.05)$
} 
The maximum concentration of the $50 \%$ ethanol-water extracts in each test was $500 \mu \mathrm{g} / \mathrm{mL}$, such that the final concentration of DMSO did not exceed $1 \%(\mathrm{v} / \mathrm{v})$ and the cytotoxicity of DMSO was $<10 \%$. The control wells contained only the complete medium and cells. The cells were treated with plant extracts for $24 \mathrm{~h}$ before the NR solution $(50 \mu \mathrm{g} / \mathrm{mL})$ in media was added to each well. Cells were further incubated for $1 \mathrm{~h}$ at $37{ }^{\circ} \mathrm{C}$ in the $5 \%$ $\mathrm{CO}_{2}$ incubator before being washed with buffer. The treated viable cells with NR were washed with $1 \mathrm{X}$ PBS buffer and were lysed with $100 \mu \mathrm{L}$ of $0.33 \%$ hydrochloric acid/isopropanol. The absorbance of NR that represented the viable cell was measured using a microplate spectrophotometer system (Anthos 2010; Biochrom, UK) with an absorbance of $520 \mathrm{~nm}$ and a reference wavelength of $650 \mathrm{~nm}$ [31]. The percentage cytotoxicity was calculated as previously described [32]. The extent of cytotoxicity toward HepG2 and Vero cells was presented as the average of half the maximal inhibitory concentration $\left(\mathrm{IC}_{50}\right)$ of the crude extract. Melphalan was used as the positive control. The selectivity of the sample against the HepG2 cancer cells was compared with the normal Vero cells and is expressed by the selectivity index (SI). The SI is the $\mathrm{IC}_{50}$ ratio in Vero cells versus HepG2 cells. Any sample with an SI value greater than three is considered to have high selectivity [32].

\section{Determination of apoptotic induction \\ Detection of nuclear morphological changes using DAPI fluorescent dye staining assay}

A DAPI staining assay was performed to identify the nuclear morphological changes in apoptotic cells as previously described [33]. Briefly, the cells were seeded at a density of $1 \times 10^{6}$ cells per well in 24-well plates in the medium and incubated for $24 \mathrm{~h}$. The cells were then treated at $2 \times$ IC50 with each plant extract or melphalan (at the highest concentration of $500 \mu \mathrm{g} / \mathrm{mL}, 0.1 \%$ DMSO) for $24 \mathrm{~h}$. The controls were the untreated wells, which contained only the complete medium and cells. After treatment, the cells were washed with $1 \times$ PBS once and harvested using centrifugation (Daihan Scientific, Seoul, Korea) at $400 \times g$, at $4{ }^{\circ} \mathrm{C}$ for $5 \mathrm{~min}$. The treated cells were fixed at $-20{ }^{\circ} \mathrm{C}$ for $10 \mathrm{~min}$ with $50 \mu \mathrm{L}$ of methanol and water $(1: 1)$. The $100 \mu \mathrm{L}(1 \mu \mathrm{g} / \mathrm{mL})$ of DAPI dye was added to the frozen cells and the mixture kept at $37^{\circ} \mathrm{C}$ for $30 \mathrm{~min}$ for staining protected from light. Excess DAPI was then removed with the supernatant by centrifugation at $400 \times g$ at $4{ }^{\circ} \mathrm{C}$ for $5 \mathrm{~min}$. A $20 \mu \mathrm{L} \mathrm{PBS}$ to glycerine ratio of 1:1 was added to the cells. The cells were analyzed by dropping aliquots of them onto slides and closed with the cover slip. The fluorescent dsDNAspecific dye stain showed a fragmented nuclei pattern of apoptotic cells compared with the intact nuclei of normal cells under $40 \times$ magnification using fluorescent microscope visualization (Eclipse 80i, Nikon, Kanagawa, Japan) [33-35]. The amount of apoptotic cells was counted and the percentage calculated.

\section{DNA fragmentation detection using DNA laddering assay}

A DNA ladder assay was performed to identify DNA fragmentation among apoptotic cells as previously described [12]. Briefly, $1 \times 10^{6}$ cells/well were seeded into a 24-well, flat-bottomed plate and incubated in a $5 \% \mathrm{CO}_{2}$ incubator at $37{ }^{\circ} \mathrm{C}$ for $24 \mathrm{~h}$. After treatment of cancer cells with $2 \times \mathrm{IC}_{50}$ of the $50 \%$ ethanol-water extracts or melphalan for $24 \mathrm{~h}$, the cells were collected and washed with medium. The DNA in the cell pellets was extracted using a FlexiGene DNA kit. Aliquots $(2 \mu \mathrm{g})$ of the DNA were analyzed using electrophoresis at $100 \mathrm{~V}$ for $40 \mathrm{~min}$ in $1.8 \%$ agarose gels containing $0.1 \%$ ethidium bromide. After electrophoresis, the DNA fragments were visualized using a UV transilluminator (Vilber Lourmat Deutschland $\mathrm{GmbH}$, Eberhardzell, Germany) and gel pictures were taken with a UV-illuminated camera (Syngene, UK).

\section{GC-MS analysis}

GC-MS analyses were performed on selected crude ethanolic extracts to identify the chemical components. A gas chromatography system (Model 6890 N; Agilent Technologies, Shanghai, China), coupled with a mass selective detector (Model 5973 N; Agilent Technologies, Delaware, USA) and a GC auto-sampler (Agilent 7683 Automatic Liquid Sampler, Santa Clara, California, USA), was employed for all analyses. Briefly, $2 \mu \mathrm{L}$ of crude extracts (10.40 mg of DC, $10.74 \mathrm{mg}$ of LC) were injected into the GC column equipped with a capillary column (122-5532 DB-5 ms, length $30.0 \mathrm{~m}$, diameter $250 \mu \mathrm{m}$, film thickness $0.25 \mu \mathrm{m})$. The injection temperature was set to $250{ }^{\circ} \mathrm{C}$. Helium was used as the carrier gas at a constant flow rate of $2 \mathrm{ml} / \mathrm{min}$. The oven temperature program was $80{ }^{\circ} \mathrm{C}$ for $6 \mathrm{~min}$, followed by a $5^{\circ} \mathrm{C} \mathrm{min}-1$ oven temperature ramp to $280{ }^{\circ} \mathrm{C}$ within $70 \mathrm{~min}$. The mass spectra were recorded with a $50-500 \mathrm{MHz}$ scanning range using mass spectrometry. The chromatograms and mass spectra of constituents of the crude extracts were evaluated by comparing their mass spectra with those in the database (Wiley 7N.l database, Agilent Technology, New York, USA).

\section{Statistical analysis}

The experiments were performed in three to five replicates and data are presented as mean \pm SD. The statistical significance of differences in multiple-group comparisons was evaluated with the analysis of variance (ANOVA) followed by Tukey's honestly significant difference test 
using SPSS version 11.5 (SPSS Inc., Chicago, IL, USA). A two-tailed Student's t test was also performed. $P$ values less than 0.05 were considered statistically significant.

\section{Results}

Cytotoxic effects and SI of plant extracts on human HCC cell line

All $50 \%$ ethanol-water crude extracts of the five plants showed a moderate to high cytotoxic effect on a human HCC cell line (HepG2). The cytotoxicity and SI values of the plant extracts for HepG2 cells are summarized in Table 2. The $\mathrm{IC}_{50}$ and SI of crude extract were demonstrated for the leaves of DC, twigs of DC, and LC. All of the crude $50 \%$ ethanol-water extracts showed significantly lower cytotoxicity than melphalan $\left(\mathrm{IC}_{50}=39.79 \pm 7.62 \mu \mathrm{g} / \mathrm{mL} ; \mathrm{SI}=4.5\right)(\mathrm{LC}: P<0.001$, CT: $P<0.001$, ES: $P<0.001$, DC leaves: $P=0.002$, DC twig: $P=0.023$, and BA: $P<0.001$, respectively). Only the crude extract of DC (twig) showed high cytotoxicity against the HepG2 cells; an effect that was significantly different to that of melphalan $(P=0.023)$.

\section{Determination of apoptosis pattern using DAPI}

Cells were stained with DAPI fluorescent dye to assess apoptosis $24 \mathrm{~h}$ after treatment of cell lines with plant extracts at $2 \times \mathrm{IC}_{50}$. Using $40 \times$ magnification, all five plant extracts were observed to cause alterations of nuclear morphology, revealing cell shrinkage, membrane blebbing, and apoptotic bodies (Fig. 1). The percentage of apoptotic cells was determined by observation using inverted microscopy for twigs of LC, CT, ES, BA, and leaves of DC. The positive control melphalan showed the highest induction of apoptosis in HepG2 $(82.5 \pm 8.0 \%)$ and twigs of DC showed the lowest $(66.0 \pm 11.5 \%)$ (Table 3$)$.

\section{Apoptosis induction by plant extracts determined by DNA laddering assay}

After treatment of HepG2 cell lines for $24 \mathrm{~h}$ with plant extracts, the DNA fragmentation of apoptotic cells was observed as DNA ladders using agarose gel electrophoresis. The results of DNA laddering showed that only LC and DC (twig) induced late-state apoptosis in HepG2 (Fig. 2); the other extracts did not induce late-stage apoptosis in HepG2 cells.

\section{Major components of DC (twig) and LC (twig) extracts using GC-MS analysis}

The GC-MS chromatograms of the DC (twig) and LC (twig) extracts were examined. GC peaks with retention times of 29, 32, 39 and 52 min were found for the two crude extracts and were used for further chemical constituent identification using MS database analysis (Tables 4 and 5).
2-Palmitoylglycerol was the only major compound that co-existed in both the DC (twig) and LC (twig) crude extracts. Pyrogallol (1,2,3-trihydroxybenzene or 1,2,3-benzenetriol) and lupeol (3 $\beta$-Lup-20(29)-en-3-ol) were the major compounds in DC (twig) crude extract. Hexadecanoic acid (abieta-8,11,13-trien-18-oic acid) and octadecenoic acid were the major compounds in the LC (twig) crude extract.

\section{Discussion}

The five plants (LC, CT, ES, DC leaves, DC twig, and BA) used in this study are found in northeastern Thailand and were selected based on their ethnopharmacology. All the crude extracts showed significantly lower cytotoxicity than melphalan $(P<0.001, P<0.001, P<0.001, P=0.002$, $P=0.023$ and $P<0.001$, respectively). Based on their cytotoxicity and selectivity classification, the extracts could be categorized as follows: (a) potentially cytotoxic $\left(\mathrm{IC}_{50}<10 \mu \mathrm{g} / \mathrm{mL}\right.$ ) with high selectivity (SI $>3$ ); (b) moderately cytotoxic $\left(\mathrm{IC}_{50}<100 \mu \mathrm{g} / \mathrm{mL}\right)$ with high selectivity (SI $>3$ ); (c) moderately cytotoxic $\left(\mathrm{IC}_{50}<100 \mu \mathrm{g} / \mathrm{mL}\right.$ ) with less selectivity ( $\mathrm{SI}<3$ ); (d) cytotoxic to only normal cells with less selectivity; and (e) nontoxic [32]. Only the crude extract of DC (twig) could be classified as highly cytotoxic toward HepG2 cells and highly selective $(\mathrm{SI}=4.5)$. The SI of this extract was not significantly different from melphalan $(P=0.959)$. DC (leaf) and other crude plant extracts had moderate cytotoxicity and less selectivity $(\mathrm{SI}<3)$. The LC showed a cytotoxic effect against normal cells with low selectivity (SI $<3$ ). To our knowledge, this study demonstrates for the first time the anticancer potential of LC extract against human HCC (HepG2) cancer cells. The extracts of CT, ES, and BA showed moderate cytotoxicity on HepG2 cells but with less selectivity.

Several chemotherapeutic compounds have been reported to induce apoptosis [36]. In apoptotic cells, specific DNA cleavage is evident on electrophoretic analysis as a characteristic ladder pattern resulting from the multiple DNA fragments of oligonucleosomal size (180$200 \mathrm{bp}$ ) [37]. The DNA ladder assay has a lower sensitivity for apoptosis detection [38] because ladder formation can only be clearly observed when the extent of oligonucleosomal cleavage is extensive. Although more than $50 \%$ of the apoptotic cells were observed with the DAPI staining assay in all of the ethanolic plant extracts, only LC and DC were positive according to the DNA ladder assay.

It was necessary to standardize the two potential crude extracts for quality control experiments as $50 \%$ ethanolwater crude extracts of DC (twig) and LC (twig) were used in the current study. We then determined which phytochemicals in the crude extracts were associated with the apoptosis effects using $\mathrm{GC}-\mathrm{MS}$ analyses. 
a Control

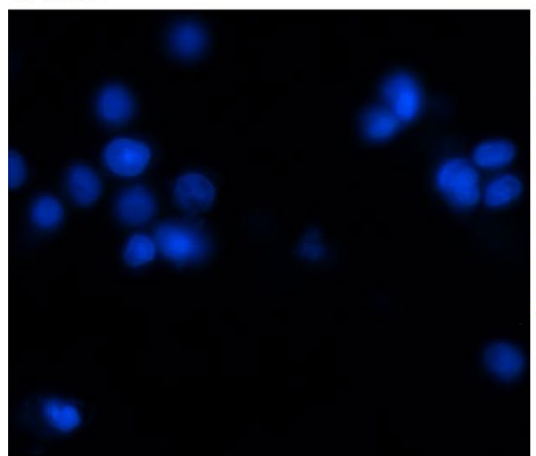

C $500 \mu \mathrm{g} / \mathrm{mL}$ of L. coromandelica (twig) extract

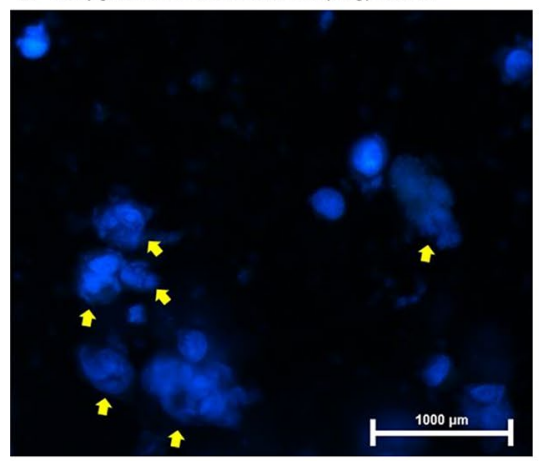

e $400 \mu \mathrm{g} / \mathrm{mL}$ of $E$. succirubrum (twig)

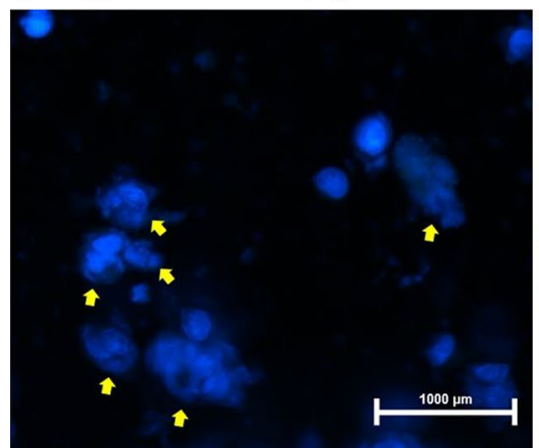

g $300 \mu \mathrm{g} / \mathrm{mL}$ of $D$. castanea (twig) extract

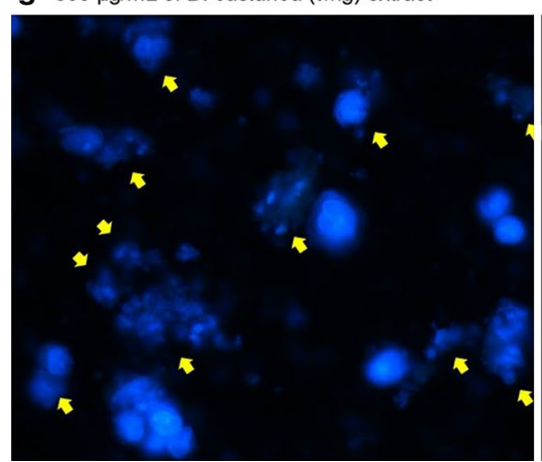

h $400 \mu \mathrm{g} / \mathrm{mL}$ of $B$. anceps (twig) extract

b melphalan

f $300 \mu \mathrm{g} / \mathrm{mL}$ of $D$. castanea (leave)

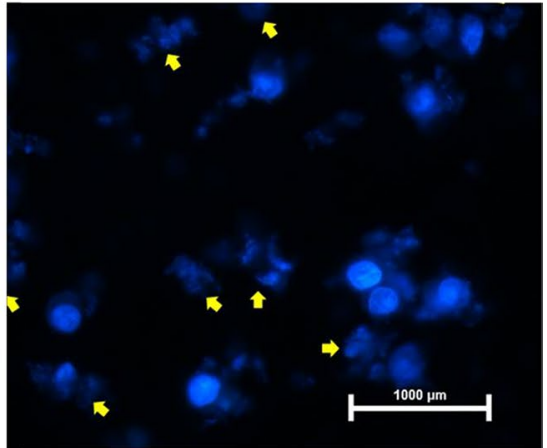

d $500 \mu \mathrm{g} / \mathrm{mL}$ of $C$. tomentosa (twig) extract
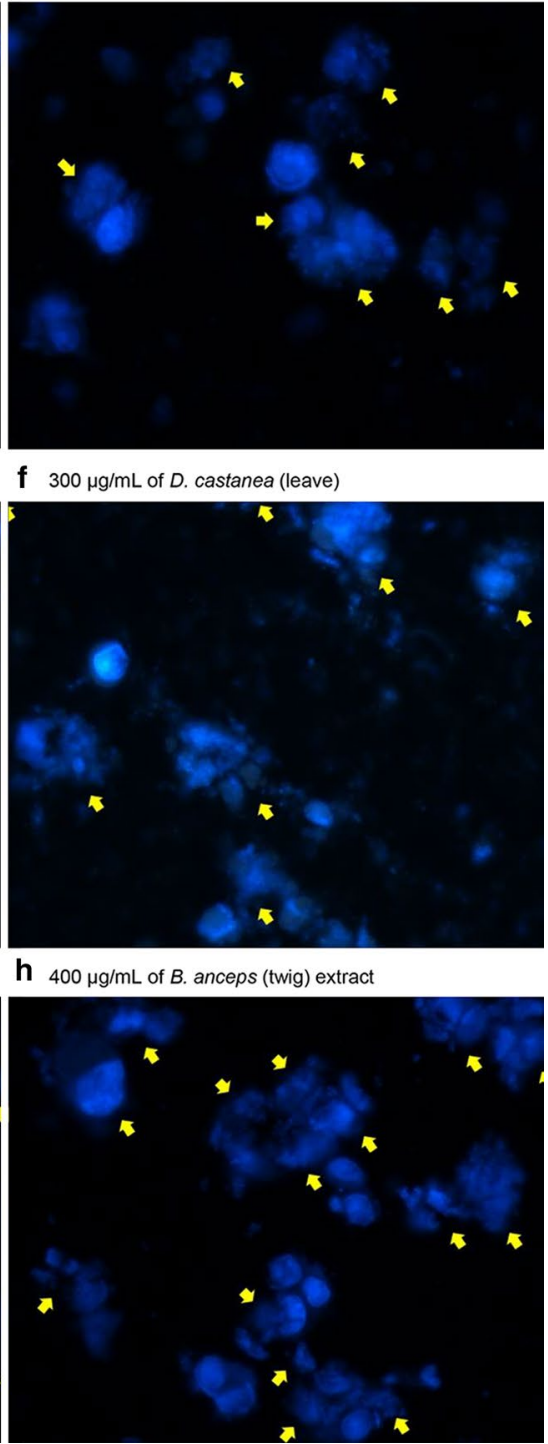

Fig. 1 Nuclei morphological change of HepG2 cells stained with DAPI fluorescent dye at 24 h. a Untreated HepG2 cells; b 80 Mg/mL of melphalan; c $500 \mu \mathrm{g} / \mathrm{mL}$ of L. coromandelica (twig) extract; $\mathbf{d} 500 \mu \mathrm{g} / \mathrm{mL}$ of C. tomentosa (twig) extract; e $400 \mu \mathrm{g} / \mathrm{mL}$ of E. succirubrum (twig) extract; f $300 \mu \mathrm{g} /$ $\mathrm{mL}$ of D. castanea (leaf) extract; $\mathbf{g} 300 \mu \mathrm{g} / \mathrm{mL}$ of D. castanea (twig) extract; and $\mathbf{h} 400 \mu \mathrm{g} / \mathrm{mL}$ of B. anceps (twig) extract. Arrows indicate apoptotic nuclei based on heterogeneous staining, DNA condensation, and apoptotic bodies at $\times 40$ objective magnification 
Table 3 Apoptosis induction of ethanolic plant extracts in HepG2 (mean \pm SD) $(n=3)$

\begin{tabular}{llll}
\hline Sample & Part & \multicolumn{2}{c}{ Apoptosis induction } \\
\cline { 3 - 4 } & & \% DAPI positive cell & DNA laddering \\
\hline L. coromandelica (LC) & Twig & $79.5 \pm 5.5$ & Positive \\
C. tomentosa (CT) & Twig & $69.0 \pm 6.5$ & Negative \\
E. succirubrum (ES) & Twig & $77.0 \pm 13.5$ & Negative \\
D. castanea (DC) & Leaves & $72.5 \pm 12.5$ & Negative \\
D. castanea (DC) & Twig & $66.0 \pm 11.5$ & Positive \\
B. anceps (BA) & Twig & $68.5 \pm 7.5$ & Negative \\
Melphalan & - & $82.5 \pm 8.0$ & Positive \\
\hline
\end{tabular}

2-Palmitoylglycerol was the major compound common to the LC (twig) and DC (twig) crude extracts. 2-Palmitoylglycerol is involved in the regulation of endogenous cannabinoid receptor activity by increasing the biological activity of 2-arachidonylglycerol, and inhibition of adenyl cyclase 2-palmitoylglycerol significantly inhibits the inactivation of 2-arachidonylglycerol by neuronal and basophilic cells [39].

2-Arachidonylglycerol inhibits the production of TNFalpha by mouse macrophages in vitro and the effect is enhanced in the presence of 2-palmitoylglycerol [40]. 2-Palmitoylglycerol is also a key component in modulating pain sensitivity as a result of its ability to interact with endocannabinoids [41]. In the present study, 2-palmitoylglycerol was the one compound found in both DC and LC extracts; however, the 2-palmitoylglycerol content was twice as low in the DC (twig) (7.5\%) than in the LC (twig) (14.0\%) and the DC extracts were more cytotoxic. It was not possible to specifically identify 2-palmitoylglycerol as the key compound; therefore, more detailed chemical identification of the plant extracts is required.

Pyrogallol was predominantly found $(18.7 \%)$ in the DC (twig) crude extract, which possessed high toxicity and selectivity against the HepG2 cells. Pyrogallol is a superoxide anion generator because it potently increases intracellular superoxide anion levels and decreases glutathione content in HeLa cells [42]. Research shows that pyrogallol-induced apoptosis resulting from the loss of mitochondrial membrane potential in calf pulmonary artery endothelial cells is accompanied by glutathione depletion [43]. In one study, the apoptosis induction of pyrogallol was indicated by a pyrogallol-type structure in a B-ring of catechins. DNA fragmentation activity was exhibited in a concentration-dependent manner in histiocytic lymphoma U937 cells after treatment with catechins containing a pyrogallol-type structure in a $\beta$-ring. Notwithstanding, catechins without a pyrogallol-type structure in any position did not show apoptosis-inducing

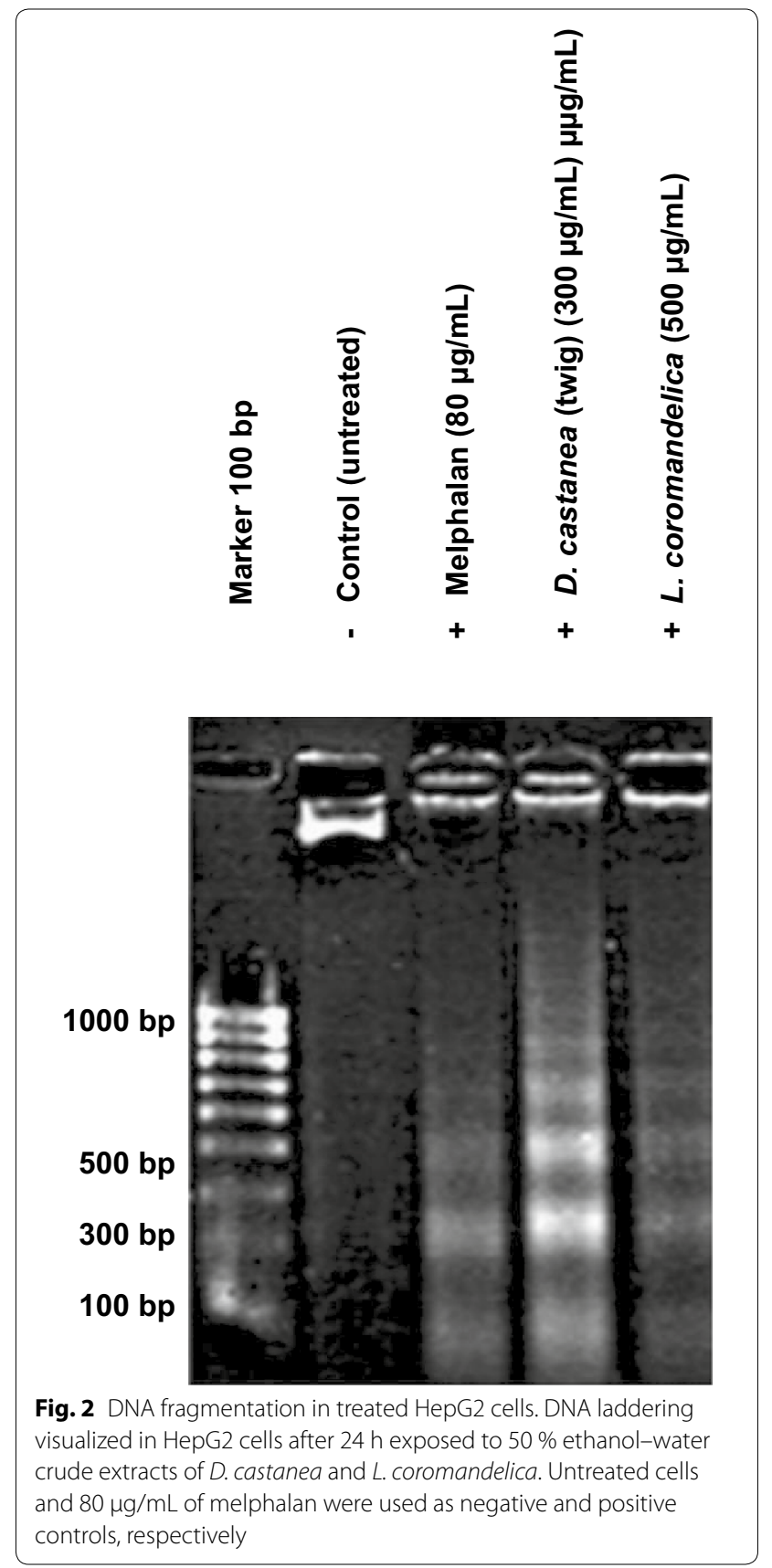

activity [44]. A 3-O-gallate residue with cis-relationship to the $\beta$-ring enhanced the activity and the destruction of a pyrogallol-type structure by its methylation reduced this effect. By contrast, a 3-O-gallate residue in transrelationship to the $\beta$-ring had little effect [44].

DC (twig) crude extract also contained lupeol as the third major compound (5.8\%). In a previous study, two hepatoma cell lines (SMMC7721 and HepG2) treated with lupeol decreased in a concentration-dependent manner (a) cell viability, (b) the induction of active 
Table 4 Gas chromatography-mass spectrometry profile of $50 \%$ ethanol-water crude extracts of $D$. castanea (twig)

\begin{tabular}{lllll}
\hline Peak no. & $\begin{array}{l}\text { Retention time } \\
(\mathbf{m i n})\end{array}$ & $\begin{array}{l}\text { \% total area } \\
\text { of prominent peak }\end{array}$ & Mass spectra & Compound \\
\hline 1 & 16.09 & 18.744 & $52,63,80,97,108,117,126$ & $1,2,3$-benzenetriol or pyrogallol \\
2 & 39.00 & 7.463 & $57,74,85,98,112,123,134,154,168,182,196,213$, & 2 -palmitoylglycerol \\
& & $227,239,257,270,283,299,312,330$ & \\
3 & 5.824 & $55,69,81,95,109,121,135,147,161,175,189,207$, & $(3 \beta)$-lup-20(29)-en-3-ol or lupeol \\
& & & $218,229,243,257,272,286,297,315,326,344$, & \\
& & $357,370,393,411,426$ & \\
& & &
\end{tabular}

Table 5 Gas chromatography-mass spectrometry profile of $50 \%$ ethanol-water crude extracts of $L$. coromandelica (twig)

\begin{tabular}{|c|c|c|c|c|}
\hline $\begin{array}{l}\text { Plants peak } \\
\text { no. }\end{array}$ & $\mathrm{RT}$ (min) & $\begin{array}{l}\text { \% total area } \\
\text { of prominent peak }\end{array}$ & Mass spectra & Compound \\
\hline 1 & 29.65 & 7.135 & $\begin{array}{l}51,60,73,83,97,107,115,129,143,157,171,185,199 \\
213,227,239,248,256\end{array}$ & Hexadecanoic acid or palmitic acid \\
\hline 2 & 30.05 & 5.013 & $\begin{array}{l}55,63,73,81,88,101,108,115,122,129,136,143,150 \\
157,167,177,185,192,199,206,213,220,227,234 \\
241,255,263,270,284\end{array}$ & Ethylhexadecanoate or ethyl palmitate \\
\hline 3 & 33.31 & 6.501 & $\begin{array}{l}55,65,73,83,97,111,121,129,143,155,163,171,185 \\
199,213,222,233,241,255,264,276,284\end{array}$ & Octadecanoic acid or stearic acid \\
\hline 4 & 37.77 & 8.621 & $\begin{array}{l}55,69,81,91,105,117,129,141,155,169,183,197 \\
211,225,239,248,247,267,276,285,300\end{array}$ & $\begin{array}{l}\text { Abieta-8,11,13-trien-18-oic acid or } \\
\text { dehydroabietic acid }\end{array}$ \\
\hline 5 & 39.07 & 14.020 & $\begin{array}{l}57,74,98,112,134,154,168,182,196,213,226,239, \\
257,270,283,330\end{array}$ & 2-palmitoylglycerol \\
\hline 6 & 42.14 & 6.166 & $\begin{array}{c}57,69,84,98,112,134,154,168,185,197,210,224 \\
241,255,267,285,298,311,327,340,358\end{array}$ & Glyceryl monostearate \\
\hline
\end{tabular}

caspase- 3 and poly (ADP-ribose) polymerase cleavage, (c) cell accumulation in the $\mathrm{S}$ phase, and (d) apoptosis. Treatment with lupeol three times a week also resulted in chemosensitization of hepatoma cells and significantly inhibited tumor growth in nude mice implanted with SMMC7721 cells [45]. Lupeol chemosensitized hepatoma cells synergistically with a PI3-kinase inhibitor (S14161) in both in vitro and in vivo models [46]. In the present study, the lupeol content of the DC (twig) extract (5.8\%) was higher than that of LC (twig) extract (1.0\%). Pyrogallol was the major compound in the DC (twig) extract but not in the LC (twig) extract. These two major compounds might contribute to the high cytotoxicity and high SI of DC (twig) extract as well as the high toxicity with lesser selectivity of LC (twig) extract.

Hexadecanoic acid and octadecenoic acid were also identified as the major compounds in LC (twig) crude extract in this study. The crystal structure (at a resolution of $2.5 \AA$ ) and kinetics studies have shown that n-hexadecanoic acid can act as an anti-inflammatory compound by inhibiting phospholipase $\mathrm{A}_{2}$ in a competitive manner [47]. This fatty acid possibly contributes as the antihepatoma cell potential in the $50 \%$ hydroethanolic herb extracts [13]. Pereira et al. [48] showed that the lipophilic extract from Marthasterias glacialis L. contained mainly palmitic acid and the sterol ergosta-7,22-dien-3-ol: these affected DNA synthesis, lipid droplets, and chromatin condensation, compatible with apoptosis in human breast cancer (MCF-7) and human neuroblastoma (SHSY5Y) cell lines.

n-Hexadecanoic acid and 9,12-octadecadienoic acid $(\mathrm{Z}, \mathrm{Z})$ are fatty acids commonly found in the $\mathrm{CO}_{2}$ supercritical fluid extraction that mediates apoptosis in human hepatoma SMMC-7721 cells, involving a reactive oxygen species-mediated mitochondrial signaling pathway [49]. The mixture of an octadecenoic acid extract-comprising mainly oleic and linoleic acids-from Euphorbia kansui resulted in a concentration-dependent reduction in the number of human gastric (SGC-7901), HCC (BEL7402), and leukemia (HL-60) cells and significantly inhibited cell proliferation, with induced apoptosis and $G_{0} / G_{1}$ phase cell cycle arrest [50]. The octadecenoic acids not only caused cell apoptosis/necrosis but also functional and structural damage to the tumor cell membrane and cell ultrastructures [50]. A fraction of the dichloromethane extract of Protaetia brevitarsis larva (composed of at least three free fatty acids: palmitic acid, (Z)9-octadecenoic acid, and octadecenoic acid) expresses 
apoptosis-inducing activity as shown by DNA laddering and caspase- 3 activation in colon 26 tumor cells [51].

\section{Conclusion}

Ethanolic extracts from DC and LC twigs induced apoptosis in the HepG2 cell line. Pyrogallol and lupeol in DC (twig) might be responsible for the cytotoxicity toward the HepG2 cancer cells.

\begin{abstract}
Abbreviations
BA: Bombax anceps Pierre var. anceps; CT: Catunaregam tomentosa (Blume ex DC.) Tirveng.: ES: Erythrophleum succirubrum Gagnep.; LC: Lannea coromandelica (Houtt.) Merr; DC: Diospyros castanea (Craib) Fletcher.; HCC: hepatocellular carcinoma; DMEM: Dulbecco's modified Eagle's medium; DMSO: dimethylsulfoxide; FBS: fetal bovine serum; GC-MS: gas chromatography/ mass spectrometry; NR: neutral red; DAPI: 4',6-diamidino-2-phenylindole; PBS: phosphate buffered saline; $I C_{50}$ : $50 \%$ inhibitory concentration; SI: selectivity index; UV: ultraviolet.
\end{abstract}

\section{Authors' contributions}

SB designed the study. CJ performed the experiments and statistical analysis. NW wrote the manuscript. NW and SB revised the manuscript. TT performed the plant authentication, collected the plants and reviewed literature. All the authors read and approved the final version of the manuscript.

\section{Author details}

${ }^{1}$ Faculty of Pharmaceutical Sciences, Khon Kaen University, Khon Kaen 40002, Thailand. ${ }^{2}$ Graduate School, Faculty of Pharmaceutical Sciences, Khon Kaen University, Khon Kaen 40002, Thailand. ${ }^{3}$ Faculty of Associate Medical Sciences, Khon Kaen University, Khon Kaen 40002, Thailand.

\section{Acknowledgements}

Financial support is acknowledged from Khon Kaen University (KKU) through the Plant Genetics Conservation Project under the Royal Initiation of HRH Princess Maha Chakri Sirindhorn, and the Incubation Researcher Project Khon Kaen University. We thank (a) Professor Dr. David Jones for advice preparing the manuscript and (b) Mr. Bryan Roderick Hamman for assistance with the English-language presentation of the manuscript.

\section{Competing interests}

The authors declare that they have no competing interests.

Received: 13 August 2014 Accepted: 16 April 2016

Published online: 23 April 2016

\section{References}

1. Jemal A, Bray F, Center MM, Ferlay J, Ward E, Forman D. Global cancer statistics. CA Cancer J Clin. 2011;61:69-90.

2. Barusrux S, Nanok C, Puthisawas W, Pairojkul C, Poovorawan Y. Viral hepatitis $\mathrm{B}, \mathrm{C}$ infection and genotype distribution among cholangiocarcinoma patients in northeast Thailand. Asian Pac J Cancer Prev. 2012;13(Suppl):83-7.

3. Liu L, Yang M, Kang R, Wang Z, Zhao Y, Yu Y, Xie M, Yin X, Livesey KM, Lotze MT, Tang D, Cao L. HMGB1-induced autophagy promotes chemotherapy resistance in leukemia cells. Leukemia. 2011;25:23-31.

4. Johnson IS, Armstrong JG, Gorman M, Jr Burnett JP. The vinca alkaloids: a new class of oncolytic agents. Cancer Res. 1963;23:1390-427.

5. Wani MC, Taylor H, Wall ME, Coggon P, McPhail A. Plant antitumor agents VI. The isolation and structure of taxol, a novel antileukemic and antitumor agent from Taxus brevifolia. J Amer Chem Soc. 1971;93:2325-7.

6. Wall ME, Wani MC, Cook CE, Palmer KH, McPhail AA, Sim GA. Plant antitumor agents $\mathrm{I}$. The isolation and structure of camptothecin, a novel alkaloidal leukemia and tumor inhibitor from Camptotheca acuminata. J Amer Chem Soc. 1966;88:3888-90.
7. Li S, Han Q, Qiao C, Song J, Lung Cheng C, Xu H. Chemical markers for the quality control of herbal medicines: an overview. Chin Med. 2008;3:7.

8. Cragg GM, Newman DJ. Plants as a source of anti-cancer agents. J Ethnopharmacol. 2005;100:72-9.

9. Kinghorn AD, Su BN, Jang DS, Chang LC, Lee D, Gu JQ, Carcache-Blanco EJ, Pawlus AD, Lee SK, Park EJ, Cuendet M, Gills JJ, Bhat K, Park HS, Mata-Greenwood E, Song LL, Jang M, Pezzuto JM. Natural inhibitors of carcinogenesis. Planta Med. 2004;70:691-705.

10. Machana S, Weerapreeyakul N, Barusrux S. Anticancer effect of the extracts from Polyalthia evecta against human hepatoma cell line (HepG2). Asian Pac J Trop Biomed. 2012;2:368-74.

11. Machana S, Weerapreeyakul N, Barusrux S, Nonpunya A, Sripanidkulchai B, Thitimetharoch T. Cytotoxic and apoptotic effects of six herbal plants against the human hepatocarcinoma (HepG2) cell line. Chin Med. 2011;6:39.

12. Nonpunya A, Weerapreeyakul N, Barusrux S. Cratoxylum formosum (Jack) Dyer ssp. pruniflorum (Kurz) Gogel. (Hóng ya mù) extract induces apoptosis in human hepatocellular carcinoma HepG2 cells through caspasedependent pathways. Chin Med. 2014;9:12.

13. Weerapreeyakul N, Nonpunya A, Barusrux S, Thitimetharoch T, Sripanidkulchai B. Evaluation of the anticancer potential of six herbs against a hepatoma cell line. Chin Med. 2012;7:15.

14. Mallavadhani UV, Panda AK, Rao YR. Pharmacology and chemotaxonomy of Diospyros. Phytochemistry. 1998;49:901-51.

15. Islam MT, Tahara S. Dihydroflavonols from Lannea coromandelica. Phytochemistry. 2000;54:901-7.

16. Sathish R, Ahmed M, Natarajan K, Lalitha KG. Evaluation of wound healing and antimicrobial activity of Lannea coromandelica (Houtt) Merr. J Pharm Res. 2010;3:1225-8.

17. Singh S, Sing GB. Hypotensive activity of Lannea coromandelica bark extract. Phytother Res. 1996;10:429-30.

18. Maiga A, Malterud KE, Diallo D, Paulsen BS. Antioxidant and 15-lipoxygenase inhibitory activities of the Malian medicinal plants Diospyros abyssinica (Hiern) F. White (Ebenaceae), Lannea velutina A. Rich (Anacardiaceae) and Crossopteryx febrifuga (Afzel) Benth. (Rubiaceae). J Ethnopharmacol. 2006;104:132-7.

19. Kannan M, Singh R, Narayanan M. Phytochemistry and immunopharmacological investigation of Rubia cordifolia Linn. (Rubiaceae). Pharmacology. 2009;3:653-62.

20. Miyagawa T, Ohtsuki T, Koyano T, Kowithayakorn T, Ishibashi M. Cassaine diterpenoid dimers isolated from Erythrophleum succirubrum with TRAlLresistance overcoming activity. Tetrahedron Lett. 2009:50:4658-62.

21. Vieira TO, Said A, Aboutabl E, Azzam M, Creczynski-Pasa TB. Antioxidant activity of methanolic extract of Bombax ceiba. Redox Rep. 2009;14:41-6.

22. Zhang X, Zhu H, Zhang S, Yu Q, Xuan L. Sesquiterpenoids from Bombax malabaricum. J Nat Prod. 2007:70:1526-8.

23. Saleem M. Lupeol, a novel anti-inflammatory and anti-cancer dietary triterpene. Cancer Lett. 2009;285:109-15.

24. You YJ, Nam NH, Kim Y, Bae KH, Ahn BZ. Antiangiogenic activity of lupeol from Bombax ceiba. Phytother Res. 2003;17:341-4.

25. Sichaem J, Surapinit S, Siripong P, Khumkratok S, Jong-aramruang J, Tippyang $\mathrm{S}$. Two new cytotoxic isomeric indole alkaloids from the roots of Nauclea orientalis. Fitoterapia. 2010;81:830-3.

26. Ebenaceae Phengklai C. In: Smitinand T, Larsen K, editors. Flora of Thailand volume 2 part 4. Bangkok: The Tistr Press Co., Ltd.; 1981. p. 281-392.

27. Chamayarit K, Staples GW, Santisuk T, Larsen K. Anacardiaceae and Convolvulaceae. In: Smitinand T, Larsen K, editors. Flora of Thailand Volume 10 Part 3. Bangkok: The Forest Herbarium, National Park, Wild life and plant Conservation Department; 2010. p. 204.

28. Larsen K, Larsen SS, Vidal E. Leguminosae-Caesalpinioideae. In: Smitinand T, Larsen K, editors. Flora of Thailand Volume 4 Part 1. Bangkok: The Tistr Press; 1984. p. 1-129.

29. Puff C, Chamchumroon V. Thai Rubiaceae with hooks and thorns. Thai For Bull. 2003;31:65-74

30. Phengklai C. Studies on Bombacaceae of Thailand. Thai For Bull. 1997;25:81-101.

31. Fotakis $G$, Timbrell JA. In vitro cytotoxicity assays: comparison of $L D H$, neutral red, MTT and protein assay in hepatoma cell lines following exposure to cadmium chloride. Toxicol Lett. 2006;160:171-7.

32. Prayong P, Barusrux S, Weerapreeyakul N. Cytotoxic activity screening of some indigenous Thai plants. Fitoterapia. 2008;79:598-601. 
33. Pocasap P, Weerapreeyakul N, Barusrux S. Cancer preventive effect of Thai rat-tailed radish (Raphanus sativus L. var. caudatus Alef). J Funct Foods. 2014;5:1372-81.

34. Plaimee P, Weerapreeyakul N, Thumanu K, Tanthanuch W, Barusrux S. Melatonin induces apoptosis through biomolecular changes, in SK-LU-1 human lung adenocarcinoma cells. Cell Prolif. 2014;47:564-77.

35. Atale N, Gupta S, Yadav UCS, Rani V. Cell-death assessment by fluorescent and nonfluorescent cytosolic and nuclear staining techniques. J Microsc. 2014;255:7-19.

36. Gunji H, Kharbanda S, Kufe D. Induction of internucleosomal DNA fragmentation in human myeloid leukemia cells by 1-beta-D-arabinofuranosylcytosine. Cancer Res. 1991;51:741-3.

37. Collins JA, Schandi CA, Young KK, Vesely J, Willingham MC. Major DNA fragmentation is a late event in apoptosis. J Histochem Cytochem. 1997:45:923-34.

38. Yasuhara S, Zhu Y, Matsui T, Tipirneni N, Yasuhara Y, Kaneki M, Rosenzweig A, Martyn JA. Comparison of comet assay, electron microscopy, and flow cytometry for detection of apoptosis. J Histochem Cytochem. 2003;51:873-85

39. Ben-Shabat S, Fride E, Sheskin T, Tamiri T, Rhee MH, Vogel Z, Bisogno T, De Petrocellis L, Di Marzo V, Mechoulam R. An entourage effect: inactive endogenous fatty acid glycerol esters enhance 2-arachidonoyl-glycerol cannabinoid activity. Eur J Pharmacol. 1998;353:23-31.

40. Gallily R, Breuer A, Mechoulam R. 2-Arachidonylglycerol, an endogenous cannabinoid, inhibits tumor necrosis factor-alpha production in murine macrophages, and in mice. Eur J Pharmacol. 2000;406:R5-7.

41. Walker JM, Krey JF, Chu CJ, Huang SM. Endocannabinoids and related fatty acid derivatives in pain modulation. Chem Phys Lipids. 2002;121:159-72.

42. Han YH, Kim SZ, Kim SH, Park WH. Pyrogallol as a glutathione depletor induces apoptosis in Hela cells. Int J Mol Med. 2008;21:721-30.
43. Han YH, Moon HJ, You BR, Kim SZ, Kim SH, Park WH. JNK and p38 inhibitors increase and decrease apoptosis, respectively, in pyrogallol-treated calf pulmonary arterial endothelial cells. Int J Mol Med. 2009;24:717-22.

44. Saeki K, Hayakawa S, Isemura M, Miyase T. Importance of a pyrogalloltype structure in catechin compounds for apoptosis-inducing activity. Phytochemistry. 2000;53:391-4.

45. He Y, Liu F, Zhang L, Wu Y, Hu B, Zhang Y, Li Y, Liu H. Growth inhibition and apoptosis induced by lupeol, a dietary triterpene, in human hepatocellular carcinoma cells. Biol Pharm Bull. 2011;34:517-22.

46. Liu F, He Y, Liang Y, Wen L, Zhu Y, Wu Y, Zhao L, Li Y, Mao X, Liu H. PI3kinase inhibition synergistically promoted the anti-tumor effect of lupeol in hepatocellular carcinoma. Cancer Cell Int. 2013;13:108.

47. Aparna V, Dileep KV, Mandal PK, Karthe P, Sadasivan C, Haridas M. Antiinflammatory property of n-hexadecanoic acid: structural evidence and kinetic assessment. Chem Biol Drug Des. 2012;80:434-9.

48. Pereira DM, Correia-da-Silva G, Valentao P, Teixeira N, Andrade PB. Palmitic acid and ergosta-7,22-dien-3-ol contribute to the apoptotic effect and cell cycle arrest of an extract from Marthasterias glacialis L. in neuroblastoma cells. Mar Drugs. 2014;12:54-68.

49. Li Q, Jiang C, Zu Y, Song Z, Zhang B, Meng X, Qiu W, Zhang L. SFE-CO extract from Typhonium giganteum Engl. tubers, induces apoptosis in human hepatoma SMMC-7721 cells involvement of a ROS-mediated mitochondrial pathway. Molecules. 2011;16:8228-42.

50. Yu F, Lu S, Shi J, McGuire PM, Wang R. Cytotoxic activity of an octadecenoic acid extract from Euphorbia kansui (Euphorbiaceae) on human tumour cell strains. J Pharm Pharmacol. 2008;60:253-9.

51. Yoo YC, Shin BH, Hong JH, Lee J, Chee HY, Song KS, Lee KB. Isolation of fatty acids with anticancer activity from Protaetia brevitarsis larva. Arch Pharm Res. 2007:30:361-5.

\section{Submit your next manuscript to BioMed Central and we will help you at every step:}

- We accept pre-submission inquiries

- Our selector tool helps you to find the most relevant journal

- We provide round the clock customer support

- Convenient online submission

- Thorough peer review

- Inclusion in PubMed and all major indexing services

- Maximum visibility for your research

Submit your manuscript at www.biomedcentral.com/submit
O Biomed Central 